\title{
Lecturers' Experience Of Using Social Media In Higher Education Courses
}

\author{
Thapanee Seechaliao, Mahasarakham University, Thailand
}

\begin{abstract}
This research paper presents lecturers' experience of using social media in higher education courses. The research methodology used a survey approach. The research instrument was a questionnaire about lecturers' experience of using social media in higher education courses. Thirty-one lecturers completed the questionnaire. The data were scored by frequency and percentage. The research results are as follows: 1) A slight majority of the lecturers were male. The largest age group was 30-35 years old. The most commonly held highest degree was a Master's. The most common academic position they held was "lecturer." The largest group was in the Department of Educational Technology and Communications. They had monthly incomes of 30,000 THB and over. They had experience of using social media, namely, Facebook, mostly through internet use on devices such as notebooks and desktops. 2) A majority of the lecturers had some experience using social media in higher education courses, mostly Facebook. However, they did not have teaching experience using social media in courses. The devices they used for facilitating social media use in courses were notebooks and desktops. Learners' role in using social media in courses was searching. Lecturers' roles were posting or creating, and commenting. Social media use in the courses was part of a blended approach that employed both regular and online instruction. The lecturers always searched for information and studied hard by themselves to cope with the problems of social media use in their courses and to enhance their skills in using social media in courses effectively.
\end{abstract}

Keywords: Lecturers' Experience; Social Media; Courses

\section{INTRODUCTION}

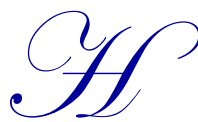

igher education courses have been designed to be more suitable for 21 st century learning, which emphasizes not only knowledge but also 21 st century skills. Learners need to catch up with the rapid changes in technology tools; use digital technologies; and use communication/networking tools and social networks appropriately to access, manage, integrate, evaluate, and create information to successfully function in a knowledge economy. Technologies become a tool to research, organize, evaluate, and communicate information. (The Partnership for 21st Century Skills, 2011) The Executive Board of Education, Mahasarakham University, has devised the Strategic Plan, 2011-2020 to develop an e-learning system and support online learning (Executive Board of Education, 2010). Therefore, lecturers have to design their courses with new technology to support learners. Then, learners will have new experiences in online learning and also can use technology to access content, complete assignments, and track their individual progress.

A tremendous amount of research has shown that social media can support online learning effectively. Lecturers can integrate social media in their courses in diverse ways. For example, they can design learners' activities to share their ideas and materials, discuss course-related topics, acquire their own knowledge, and then create a learning community (Kultawanich, Suwatthipong, Tawitsri, \& Sakulrat, 2011; Nilsook \& Wannapiroon, 2012; Tiryakioglu \& Erzurum, 2011; Wannapiroon \& Supa, 2012). Social media becomes technology in education and can benefit instruction. Thus, most lecturers have adopted integrated social media in the courses they teach (Moran, Seaman, \& Tinti-Kane, 2011; Srichoosin \& Satiman, 2012). Likewise, learners have adopted integrated social media for learning (Roblyer \& others, 2010). 
On the other hand, theory and empirical tests investigating faculty decisions to adopt Web 2.0 technologies found that while some faculty members feel that some Web 2.0 technologies could improve students' learning, their interaction with faculty and with other peers, their writing abilities, and their satisfaction with the course; few choose to use them in the classroom. Additional results indicated that faculty members' attitude and their perceived behavioral control are strong indicators of their intention to use Web 2.0. A number of implications are drawn highlighting how the use of Web 2.0 could be useful in the classroom. (Ajjan \& Hartshorne, 2008)

Lecturers who taught in the Faculty of Education, Mahasarakham University have different generational and adopter characteristics that affect their adoption of social media in courses. This research focuses on how much lecturers used appropriate technology and tried to use social media in their courses, as well as their experiences of using social media in courses. The findings can help instructional designers and lecturers with ideas to improve their courses.

\section{LITERATURE REVIEW}

Popular social media such as Facebook, YouTube, blogs, wikis, Twitter, Myspace, LinkedIn, Flickr, SlideShare, and podcasts are widely used in higher education. Most lecturers believe in social media use and incorporate it into their teaching both in and outside of class. They post content that students are required to view or read outside class. Some course assignments require students to read or view social media or to comment on or post to social media sites. (Moran, Seaman, \& Tinti-Kane, 2011) Ruangsawat (2010) studied lifestyles and behaviors in the use of social networks by office workers in Bangkok, Thailand and found that most participants in the study sample were members of Facebook. They always accessed this site at home through a computer. They generally chatted with their friends, updated their status, uploaded pictures, and found or shared data. Using social media in courses can benefit instruction. Therefore, lecturers and learners have widely adopted social media in courses.

Lecturers in the Faculty of Education, Mahasarakham University have different generational and adopter characteristics that affect their adoption of social media in courses. Rogers (2003) presents these adopter categories as ideal types. Below is an overview of the main characteristics and values of each adopter category, which will be followed by more detailed generalizations.

\section{Innovators: Venturesome}

Venturesomeness is almost an obsession with innovators. Their interest in new ideas leads them out of a local circle of peer networks and into more cosmopolitan social relationships. Communication patterns and friendships among a clique of innovators are common, even though these individuals may be quite geographically distanced. Being an innovator has several prerequisites. Control of substantial financial resources is helpful in absorbing the possible losses from an unprofitable innovation. The ability to understand and apply complex technical knowledge is also needed. The innovator must be able to cope with a high degree of uncertainty about an innovation at the time he or she adopts it

The salient value of the innovator is venturesomeness, due to a desire for the rash, the daring, and the risky. The innovator must also be willing to accept an occasional setback when a new idea proves unsuccessful, as inevitably happens. While an innovator may not be respected by other members of a local system, he or she plays an important role in the diffusion process: that of launching the new idea in the system by importing the innovation from outside of the system's boundaries. Thus, the innovator plays a gatekeeping role in the flow of new ideas into a system.

\section{Early Adopters: Respect}

Early adopters are a more integrated part of the local social system than are innovators. Whereas innovators are cosmopolites, early adopters are localites. This adopter category, more than any other, has the highest degree of opinion leadership in most systems. Potential adopters look to early adopters for advice and information about an innovation. The early adopter is considered by many to be "the individual to check with" before adopting a new idea. This adopter category is generally sought by change agents as a local missionary for speeding the diffusion process. Because early adopters are not too far ahead of the average individual in innovativeness, they serve as a role 
model for many other members of a social system. Early adopters help trigger a critical mass when they adopt an innovation.

The early adopter is respected by his or her peers and is the embodiment of successful, discrete use of new ideas. The early adopter knows that to continue to earn this esteem of his or her colleagues and to maintain a central position in the communication networks of the system, he or she must make judicious innovation decisions. The early adopter decreases uncertainty about a new idea by adopting it and then conveying a subjective evaluation of the innovation to near peers through interpersonal networks. In one sense, early adopters put their stamp of approval on a new idea by adopting it.

\section{Early Majority: Deliberate}

The early majority adopt new ideas just before the average member of a system. They interact frequently with their peers but seldom hold positions of opinion leadership in a system. Their unique location between very early and relatively late adopters makes them an important link in the diffusion process. They provide interconnectedness in the system's interpersonal networks. The early majority are one of the largest adopter categories, making up one third of all members of a system.

The early majority may deliberate for some time before completely adopting a new idea. Their innovationdecision period is relatively longer than that of the innovators and early adopters.

\section{Late Majority: Skeptical}

The late majority adopt new ideas just after the average member of a system. Like the early majority, the late majority make up one third of the members of a system. Adoption may be both an economic necessity for the late majority and the result of increasing peer pressure. Innovations are approached with a skeptical and cautious air, and the late majority do not adopt until most others in their system have already done so. The weight of system norms must definitely favor an innovation before the late majority are convinced to adopt. Peer pressure is necessary to motivate adoption. Their relatively scarce resources mean that most of the uncertainty about a new idea must be removed before the late majority feel that it is safe to adopt.

\section{Laggards: Traditional}

Laggards are the last in a social system to adopt an innovation. They possess almost no opinion leadership. Laggards are the most localite of all adopter categories in their outlook. Many are near isolates in the social networks of their system. The point of reference for the laggard is the past. Decisions are often made in terms of what has been done previously, and these individuals interact primarily with others who also have relatively traditional values. Laggards tend to be suspicious of innovations and of change agents. Their innovation decision process is relatively lengthy, with adoption and use lagging far behind awareness or knowledge of a new idea. Resistance to innovations on the part of laggards may be entirely rational from the laggards' viewpoint, as their resources are limited and they must be certain that a new idea will not fail before they adopt it. The laggard's precarious economic position forces the individual to be extremely cautious in adopting innovations.

The Executive Board of Education, Mahasarakham University created the Strategic Plan, 2011-2020 to develop an e-learning system and support online learning (Executive Board of Education, 2010). Therefore, lecturers in the Faculty of Education, Mahasarakham University have to design their courses with appropriate technology and use social media in their courses to support online learning. Roger (2003) showed that implementation occurs when an individual (or other decision-making unit) puts an innovation to use. Until the implementation stage, the innovation decision process is a strictly mental exercise of thinking and deciding. However, implementation involves an overt behavior change as the new idea is actually put into practice. It is one thing for an individual to decide to adopt a new idea but quite a different thing to put the innovation to use, as problems in exactly how to use the innovation crop up at the implementation stage. Implementation usually follows the decision stage rather directly, unless it is held up by some logistical problem, such as temporary unavailability of the innovation. In Thailand, Tantaphalin (2010) studied the causal factors affecting the decision process for adopting blended learning by Faculty of Education instructors. He used Roger's innovation decision process theory and found that the factors 
affecting the persuasion, decision, and adoption phases were the characteristics of blended learning. Thus, if lecturers do not have a chance to share experiences of using social media in courses with others and have no ideas to improve their course, they may reject using social media in courses.

Lecturers' experiences of using social media in their courses can show how much lecturers use appropriate technology, use social media in their courses, and try to solve problems while using social media in their courses. The research findings can help instructional designers and lecturers gain ideas to improve their courses.

\section{RESEARCH METHODOLOGY}

The research methodology used a survey approach to investigate the lecturers' experience of using social media in higher education courses for lecturers in the Faculty of Education, Mahasarakham University. The research instrument was a questionnaire about lecturers' experience of using social media in higher education courses. It consisted of 47 statements rated on a five-point Likert scale $(1=$ strongly disagree, $2=$ disagree, $3=$ undecided, $4=$ agree, and $5=$ strongly agree). The instrument was validated by three experts in the diffusion of innovations, five experts in online learning, and three experts in educational research and evaluation using the index of item-objective congruence (IOC). The IOC values ranged from 0.73 to 1.00 . The instrument was applied to participants in a pilot study, who were 125 lecturers from Chulalongkorn University, Srinakharinwirot University, Kasetsart University, Silpakorn University, and Khon Kean University. The reliability coefficient was calculated by using Cronbach's equation, and it was 0.94 , which is suitable for conducting the study. Thirty-one lecturers completed the study. The data were scored by frequency and percentage.

\section{RESULTS}

The results of this research were the lecturers' experiences of using social media in higher education courses as follows:

Table 1. Frequency distribution and percentage of the lecturers' background characteristics

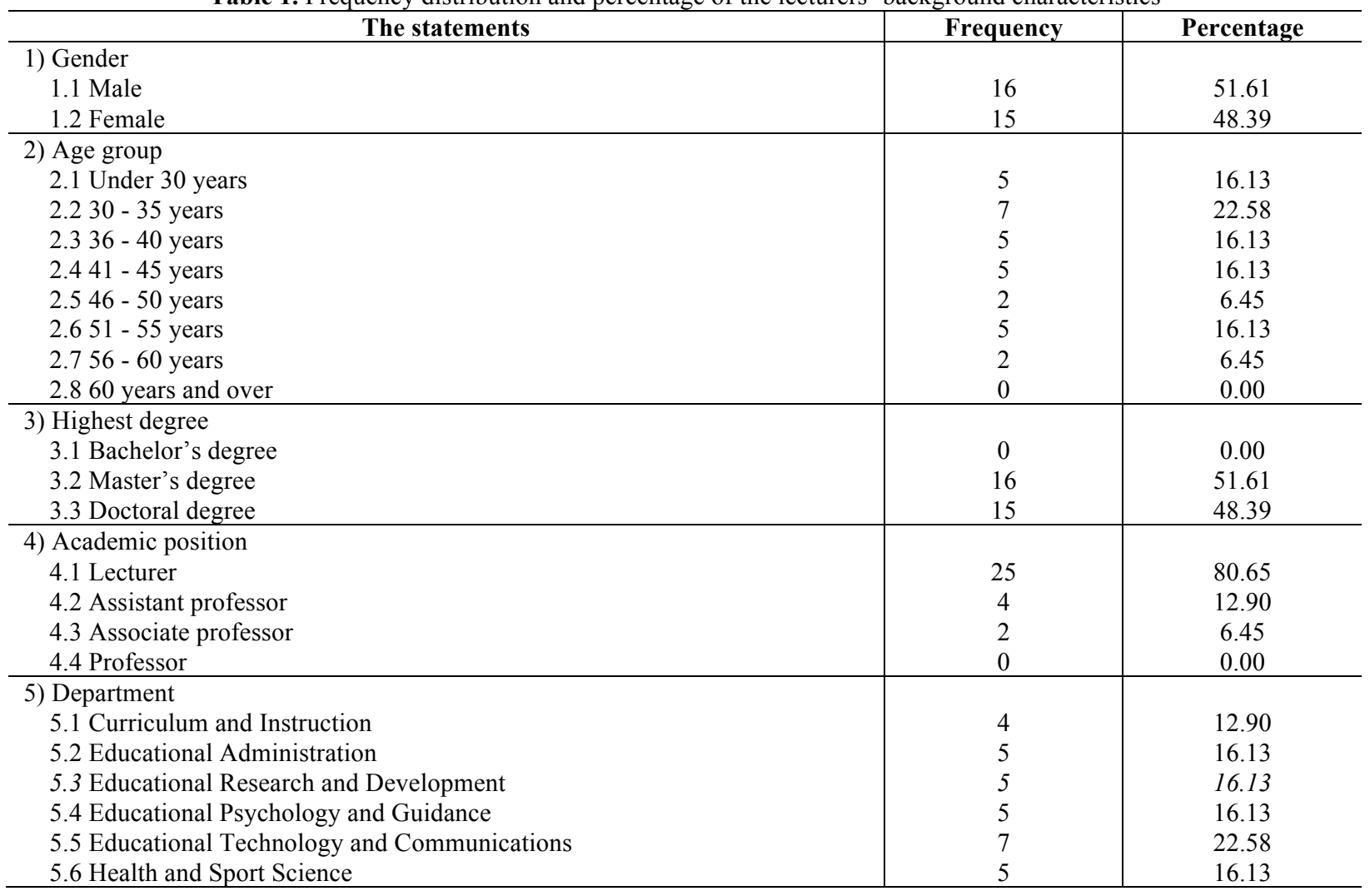


(Table 1 continued)

\begin{tabular}{|c|c|c|}
\hline The statements & Frequency & Percentage \\
\hline $\begin{array}{l}\text { 6) Monthly income (U.S. dollar to Thai baht exchange rate is at a current level } \\
\text { of approximately } 32.52) \\
6.112,000-18,000 \text { THB } \\
6.218,001-24,000 \text { THB } \\
6.324,001-30,000 \text { THB } \\
6.430,000 \text { THB and over }\end{array}$ & $\begin{array}{c}5 \\
8 \\
3 \\
15 \\
\end{array}$ & $\begin{array}{c}16.13 \\
25.80 \\
9.68 \\
48.39 \\
\end{array}$ \\
\hline $\begin{array}{l}\text { 7) Experience of using social media } \\
\text { 7.1 Facebook } \\
\text { 7.2 Twitter } \\
\text { 7.3 YouTube } \\
\text { 7.4 Blogs } \\
\text { 7.5 Myspace } \\
\text { 7.6 Wikis } \\
\text { 7.7 LinkedIn } \\
\text { 7.8 Flickr } \\
\text { 7.9 Podcasts } \\
\text { 7.10 Line, Tango, Skype, Google Hangout }\end{array}$ & $\begin{array}{c}31 \\
15 \\
28 \\
14 \\
9 \\
11 \\
7 \\
3 \\
2 \\
2 \\
\end{array}$ & $\begin{array}{c}25.41 \\
12.30 \\
22.95 \\
11.47 \\
7.37 \\
9.02 \\
5.74 \\
2.46 \\
1.64 \\
1.64 \\
\end{array}$ \\
\hline $\begin{array}{l}\text { 8) Experience of using social media through internet on devices } \\
\text { 8.1 Smartphone } \\
\text { 8.2 Tablet } \\
\text { 8.3 Notebook } \\
\text { 8.4 Desktop }\end{array}$ & $\begin{array}{l}26 \\
19 \\
27 \\
27 \\
\end{array}$ & $\begin{array}{l}26.00 \\
19.00 \\
27.00 \\
27.00\end{array}$ \\
\hline
\end{tabular}

Table 1 presents the lecturers' background information on social media use in higher education courses. A slight majority of the lecturers were male (51.61\%). The largest age group was 30-35 years old $(22.58 \%)$. The most commonly held highest degree was a Master's (51.61\%). The most common academic position was "lecturer" $(80.65 \%)$, and the most common department was the Department of Educational Technology and Communications $(22.58 \%)$. Almost half of the participants had a monthly income approximately 30,000 THB or over (48.39\%), and $25.41 \%$ had experience of using social media, mostly Facebook. Their experience of using social media was through internet on devices that were notebooks and desktops (27.00\%).

Table 2. Frequency distribution and percentage of the lecturers' experience of using social media in higher education courses

\begin{tabular}{|c|c|c|}
\hline The statements & Frequency & Percentage \\
\hline $\begin{array}{l}\text { 1) Using social media in courses } \\
\text { 1.1 Ever used } \\
\text { 1.2 Never used }\end{array}$ & $\begin{array}{c}22 \\
9\end{array}$ & $\begin{array}{l}70.97 \\
29.03\end{array}$ \\
\hline $\begin{array}{l}\text { 2) Experience of using social media in courses } \\
\text { 2.1 Facebook } \\
\text { 2.2 Twitter } \\
\text { 2.3 YouTube } \\
\text { 2.4 Blogs } \\
\text { 2.5 Myspace } \\
\text { 2.6 Wikis } \\
\text { 2.7 LinkedIn } \\
\text { 2.8 Flickr } \\
\text { 2.9 Podcasts } \\
\text { 2.10 Google Plus, Multiply }\end{array}$ & $\begin{array}{c}22 \\
1 \\
21 \\
4 \\
0 \\
4 \\
2 \\
0 \\
0 \\
3 \\
\end{array}$ & $\begin{array}{c}38.59 \\
1.76 \\
36.84 \\
7.02 \\
0.00 \\
7.02 \\
3.51 \\
0.00 \\
0.00 \\
5.26\end{array}$ \\
\hline $\begin{array}{l}\text { 3) Teaching experience of using social media in courses } \\
\text { 3.1 None } \\
\text { 3.2 Under } 1 \text { year } \\
3.31 \text { - } 2 \text { years } \\
3.43 \text { - } 4 \text { years } \\
\text { 3.5 } 5 \text { years and over }\end{array}$ & $\begin{array}{l}9 \\
3 \\
7 \\
7 \\
5\end{array}$ & $\begin{array}{c}29.03 \\
9.68 \\
22.58 \\
22.58 \\
16.13\end{array}$ \\
\hline
\end{tabular}


(Table 2 continued)

\begin{tabular}{|c|c|c|}
\hline The statements & Frequency & Percentage \\
\hline $\begin{array}{l}\text { 4) Devices for using social media in courses } \\
\text { 4.1 Smartphone } \\
\text { 4.2 Tablet } \\
\text { 4.3 Notebook } \\
\text { 4.4 Desktop }\end{array}$ & $\begin{array}{l}13 \\
13 \\
18 \\
18\end{array}$ & $\begin{array}{l}20.97 \\
20.97 \\
29.03 \\
29.03\end{array}$ \\
\hline $\begin{array}{l}\text { 5) Learners' role in social media use in courses } \\
5.1 \text { Search }\end{array}$ & 21 & 26.92 \\
\hline $\begin{array}{l}\text { 5.2 Post or Create } \\
\text { 5.3 View } \\
\text { 5.4 Comment } \\
\text { 5.5 Others: Discuss, Create, Communicate }\end{array}$ & $\begin{array}{l}18 \\
18 \\
18 \\
3\end{array}$ & $\begin{array}{c}23.08 \\
23.08 \\
23.08 \\
3.84\end{array}$ \\
\hline $\begin{array}{l}\text { 6) Lecturers' role in facilitating social media use in courses } \\
\text { 6.1 Search } \\
\text { 6.2 Post or Create } \\
6.3 \text { View } \\
\text { 6.4 Comment } \\
\text { 6.5) Others: Discuss, Assign, Communicate }\end{array}$ & $\begin{array}{l}17 \\
18 \\
14 \\
18 \\
3\end{array}$ & $\begin{array}{c}24.29 \\
25.71 \\
20.00 \\
25.71 \\
4.29\end{array}$ \\
\hline $\begin{array}{l}\text { 7) Characteristics of online instruction with social media use in courses } \\
7.1 \text { Blend between regular instruction and online } \\
7.2 \text { Online only }\end{array}$ & $\begin{array}{c}21 \\
1\end{array}$ & $\begin{array}{c}95.45 \\
4.55\end{array}$ \\
\hline $\begin{array}{l}\text { 8) How to cope with social media use problems in courses based on lecturers' } \\
\text { experience } \\
\text { 8.1 Search for information, study hard by myself } \\
\text { 8.2 Share experience with peers } \\
\text { 8.3 Share experience with technician in faculty } \\
\text { 8.4 Share experience with social media members } \\
\text { 8.5 Change back to regular instruction }\end{array}$ & $\begin{array}{c}21 \\
12 \\
5 \\
4 \\
1\end{array}$ & $\begin{array}{l}48.84 \\
27.91 \\
11.63 \\
9.30 \\
2.32\end{array}$ \\
\hline $\begin{array}{l}\text { 9) How to enhance skills of using social media in courses effectively } \\
\text { 9.1 Search for information, study hard by myself } \\
\text { 9.2 Share experience with peers } \\
\text { 9.3 Share experience with technician in faculty } \\
\text { 9.4 Share experience with social media members }\end{array}$ & $\begin{array}{l}21 \\
11 \\
4 \\
7\end{array}$ & $\begin{array}{c}48.84 \\
25.58 \\
9.30 \\
16.28\end{array}$ \\
\hline
\end{tabular}

Table 2 presents the results regarding the lecturers' experience of using social media in higher education courses. Most lecturers had used social media in their courses $(70.97 \%)$, with Facebook being the most common social media site $(38.59 \%)$. However, many lecturers did not have teaching experience using social media in courses $(29.03 \%)$. The devices they used for accessing social media in courses were notebooks and desktops $(29.03 \%)$. The most common learners' role in social media use in courses was searching $(26.92 \%)$. Lecturers' roles in facilitating social media in courses were posting or creating, and commenting $(25.71 \%)$. Online instruction with social media use in courses was blended between regular and online instruction (95.45\%). The lecturers always searched for information and studied hard by themselves to cope with social media use problems in courses $(48.84 \%)$.

\section{DISCUSSION AND CONCLUSION}

A slight majority of the lecturers were male, and the largest age group was 30-35 years old. The most commonly held highest degree was a Master's. The most common academic position was "lecturer." The largest group was in the Department of Educational Technology and Communications, and the most common monthly salary range was approximately $30,000 \mathrm{THB}$ and over. These results are similar to the adopter categories of innovators because the lecturers were interested in a new idea, namely, using social media in daily life. They also had high monthly incomes, which are substantial financial resources. As many held Master's degrees, they were able to understand and apply complex technical knowledge to cope with uncertain problems about the innovation at the time. (Rogers, 2003) Their experience of using social media was mostly through Facebook. They had experience using social media through the internet on devices such as notebooks and desktops. The result is similar to the previous study in Thailand because most of the office workers in Bangkok were members of Facebook. They always 
accessed this site at home through a computer. They generally chatted with their friends, updated their status, uploaded pictures, found and shared data. (Ruangsawat, 2010)

The lecturers had experience using social media in higher education courses. Most had used social media in their courses at least once. However, some lacked teaching experience using social media in courses. They always searched for information and studied hard by themselves to cope with social media use problems in their courses. They searched for information and studied hard by themselves to enhance their skills of using social media in courses effectively. These results are similar to the adopter categories of innovators. Although the lecturers did not have teaching experience using social media in courses, they were interested in a new idea, that is, using social media in their courses. The most commonly held highest degree was a Master's, which has several prerequisites. Innovators must be able to cope with high uncertainty about an innovation at the time they adopt. Lecturers are types of early adopters who are respected by their peers. They communicate, decrease uncertainty, and evaluate the innovation for near peers. Lecturers also are types of the early majority who interact frequently with their peers but seldom hold positions of opinion leadership in a system. (Rogers, 2003) Finally, they are adopters of social media use in their courses. Their experience with social media use in courses was mostly through Facebook. These results are similar to the previous study in which Facebook was the most popular platform for online social networking among university students (Kabilan \& others, 2010). Facebook has the potential to become a valuable resource to support educational communications and collaborations among lecturers. Therefore, students adopted Facebook widely. (Roblyer \& others, 2010) Most office workers also had lifestyles and behaviors of using Facebook (Ruangsawat, 2010). The devices they used to access social media in courses were notebooks and desktops. These results are similar to the previous study in Thailand because the office workers in Bangkok always accessed Facebook at home through a computer (Ruangsawat, 2010). Learners' main role in social media use in courses was searching. Lecturers' roles in facilitating social media in courses were posting or creating, and commenting. These results are similar to the finding that most lecturers believe in social media use and employ social media in their teaching both in and outside class. Lecture content was posted for students to view or read outside class. Some course assignments required students to read or view social media or to comment on or post to social media sites. (Moran, Seaman, \& Tinti-Kane, 2011) Using social media in courses can benefit instruction. Therefore, most lecturers and learners adopted integrated social media in courses widely. Additionally, these results are similar to the implementation stage that involves an overt behavior change as a new idea is actually put into practice (Rogers, 2003). Online instruction with social media use was blended between regular and online instruction. These results are similar to the factors affecting the persuasion, decision, and adoption phases that were the characteristics of blended learning. Thus, if lecturers do not have a chance to share experiences of using social media in courses with others and have no ideas to improve their courses, they may reject using social media in courses (Tantaphalin, 2010). These research results identified how much lecturers used appropriate technology and tried to use social media in their courses, as well as their experiences of using social media in courses. It can help instructional designers and lecturers gain ideas to make their courses more suitable for $21^{\text {st }}$ century learning and also support the Strategic Plan, 2011-2020 of the Executive Board of Education, Mahasarakham University.

\section{ACKNOWLEDGEMENTS}

This work has been supported by the Mahasarakham University Development Fund, Mahasarakham University, Thailand under the international conference grant.

\section{AUTHOR INFORMATION}

Thapanee Seechaliao received a Ph.D. in 2010 from Chulalongkorn University, Thailand, and a scholarship from the Commission on Higher Education, Thailand under the grant program Strategic Scholarships for Frontier Research Network for the Ph.D. Program Thai Doctoral degree. She received the Best Paper Award from the 2012 International Conference on Education and Management Innovation, Singapore and the Dissertation Award 2013 from the National Research Council of Thailand (NRCT). Dr. Seechaliao is currently a lecturer in the Educational Technology and Communications Department, Faculty of Education, Mahasarakham University, Thailand. Her fields of research include educational technology, instructional design, and diffusion of innovations. E-mail: thapanee.see@msu.ac.th or thapanee.see@ hotmail.com 


\section{REFERENCES}

Ajjan, A., \& Hartshorne, R. (2008). Investigating Faculty Decisions to Adopt Web 2.0 Technologies: Theory and Empirical Tests. Internet and Higher Education, 11(2), 71-80.

Executive Board of Education. (2010). The Strategic Plan, 2011-2020. Mahasarakham: Faculty of Education, Mahasarakham University.

Kabilan, M.K., \& others. (2010). Facebook: An Online Environment for Learning of English in Institutions of Higher Education? Internet and Higher Education, 13(4), 179-187.

Kultawanich, K., \& others. (2011). Facebook: The Practice of Social Constructivist in Blended Learning. In Chawalert Lertchalolarn \& others (Eds.), Proceedings of The National e-Learning Conference. Open: Learning-Open the World (pp. 367-373). Bangkok, Thailand: Thailand Cyber University Project.

Moran, M., Seaman, J., \& Tinti-Kane., H. (2011). Teaching, Learning, and Sharing: How Today's Higher Education Faculty Use Social Media. Boston, MA: Pearson Learning Solutions.

Nilsook, P., \& Wannapiroon, P. (2012). e-Learning Effects of Integrated Learning using Social Media in e-Learning. In Chawalert Lertchalolarn \& others (Eds.), Proceedings of The National e-Learning Conference Integrating ASEAN Online learning: Policy and Process (pp. 170-176). Bangkok, Thailand: Thailand Cyber University Project.

Roblyer, M.D., \& others. (2010). Findings on Facebook in Higher education: A Comparison of College Faculty and Student Uses and Perceptions of Social Networking Sites. The Internet and Higher Education, 13(3), 134140 .

Rogers, E.M. (2003). Diffusion of Innovations. (5th ed.). NY: The Free Press.

Ruangsawat, P. (2010). Lifestyles and Behaviors in Using Social Network by Office Workers in Bangkok. Bangkok, Thailand: Thammasat University.

Srichoosin, A., \& Satiman, A. (2012). The Social Network Usage Behavior of Undergraduate Students in Faculty of Education, Government University. In Chawalert Lertchalolarn \& others (Eds.), Proceedings of The National e-Learning Conference Integrating ASEAN Online learning: Policy and Process (pp. 204-211). Bangkok, Thailand: Thailand Cyber University Project.

Tantaphalin, P., (2010). Causal factors affecting adoption decision process for blended learning of faculty of education instructors. Bangkok, Thailand: Chulalongkorn University.

The Partnership for 21 st Century Skills. (2013, April 12). Framework for 21 st Century Learning. Retrieved from http://www.p21.org/storage/documents/1._p21_framework_2-pager.pdf

Tiryakioglu. F., \& Erzurum. F. (2011). Use of Social Networks as an Education Tool. Contemporary Educational Technology, 2(2), 135-150.

Wannapiroon, P., \& Supa, W., (2012). Collaborative Learning Model through Social Media for Supporting Communications Project-based Learning for Postgraduate Students. In Chawalert Lertchalolarn \& others (Eds.), Proceedings of The National e-Learning Conference Integrating ASEAN Online learning: Policy and Process (pp. 161-169). Bangkok, Thailand: Thailand Cyber University Project. 